http:/ /dx.doi.org/10.1590/0104-07072017003340015

\title{
NAIVE WORLD AWARENESS IN THE PEDAGOGICAL PRACTICE OF HEALTHCARE PROFESSORS ${ }^{1}$
}

\author{
Bruna Pedroso Canever², Marta Lenise do Prado ${ }^{3}$, Diana Coelho Gomes", \\ Bruna Helena de Jesus 5 , Vânia Marli Schubert Backes ${ }^{6}$
}

${ }^{1}$ Article extracted from the dissertation - Docente universitário da área da saúde: consciência de si e de mundo para uma prática pedagógica transformadora, presented to the Programa de Pós-Grauação em Enfermagam (PEN) da Universidade Federal de Santa Catarina (UFSC), in 2014.

2 PhD. in Nursing. Postdoctoral student at PEN/UFSC. Florianópolis, Santa Catarina, Brazil. E-mail: brunacanever@gmail.com

${ }^{3}$ PhD. in Nursing. Professor, Nursing Department PEN/UFSC. CNPq researcher. Florianópolis, Santa Catarina, Brazil. E-mail: marta.lenise@ufsc.br

${ }^{4}$ Msc. in Nursing. Florianópolis, Santa Catarina, Brazil. E-mail: dianacoelhog@yahoo.com.br

${ }^{5}$ Msc. in Nursing. Enfermeira da Estratégia da Saúde da Família da Prefeitura de Palhoça. Palhoça, Santa Catarina, Brazil. E-mail: brunahelena_j@yahoo.com.br

${ }^{6} \mathrm{PhD}$. in Nursing. Professor, Nursing Department and at PEN/UFSC. CNPq researcher. Florianópolis, Santa Catarina, Brazil. E-mail: vania.backes@ufsc.br

\section{ABSTRACT \\ Objective: to understand how Freire's naive world awareness is expressed in the pedagogical practices of healthcare professors using Shulman's base knowledge categories. \\ Method: it is a descriptive, exploratory and analytical study, with a qualitative approach. Data collection occurred through open interviews and non-participant observation from May to December 2013, with the participation of 21 professors from a public university in the Southern Region of Brazil. Data systematization was based on the Minayo's operative proposal. \\ Results: analysis led to a central category: "Naive world awareness of healthcare workers". Data were articulated with Shulman's base knowledge categories for teaching. \\ Conclusion: the professors' pedagogical practice was still linked to traditional teaching, which encourages memorization, and to students' low participation and reflection on their educational process. \\ DESCRIPTORS: Faculty. Health education. Professional training. Professional competence. \\ CONSCIÊNCIA DE MUNDO INGÊNUA NA PRÁTICA PEDAGÓGICA DE DOCENTES DA ÁREA DA SAÚDE ${ }^{1}$}

\section{RESUMO}

Objetivo: compreender como a consciência de mundo ingênua de Freire se expressa na prática pedagógica de docentes da área da saúde, a partir das categorias de conhecimento-base de Shulman.

Método: pesquisa exploratória, descritiva e analítica, de abordagem qualitativa. A coleta de dados ocorreu por meio de entrevista aberta e observação não participante, realizadas de maio a dezembro de 2013, com participação de 21 docentes de uma universidade pública da região sul do Brasil. A sistematização dos dados foi realizada com base na proposta operativa de Minayo.

Resultados: da análise, emergiu a categoria central "Consciência de mundo ingênua dos docentes da área da saúde". Os dados foram articulados a partir das categorias de conhecimento base para o ensino de Shulman.

Conclusão: a prática pedagógica dos docentes ainda estava atrelada ao ensino tradicional, que estimulava a memorização, e à pouca participação e reflexão dos discentes em seu processo de formação.

DESCRITORES: Docentes. Educação em saúde. Capacitação profissional. Competência profissional. 


\section{CONCIENCIA DE MUNDO INGENUA EN LA PRÁCTICA PEDAGÓGICA DE LOS DOCENTES DE LA SALUD}

\section{RESUMEN}

Objetivo: comprender cómo se expresa el mundo de la conciencia ingenua de Freire en la práctica de los docentes de area de la salud las categorías de Shulman cómo base de conocimientos.

Metodo: investigación exploratoria, analítica y descriptiva, con enfoque cualitativo. La recolección de datos ocurrió por medio de entrevistas abiertas y observación no participante, realizadas entre mayo y diciembre de 2013, con la participación de 21 profesores de una universidad pública en el Sur de Brasil. La sistematización de los datos se basa en la propuesta operativa de Minayo.

Resultados: la análisis surgió la categoría central: "Conciencia de mundo ingenua de los docentes de la salud". Los datos fueron articulados a partir de las categorías de base de conocimientos para la enseñanza de Shulman.

Conclusión: la práctica pedagógica de los docentes estaba vinculado a la enseñanza tradicional, que incitaban la memorización, y a la baja participación y la reflexión de los alumnos en su proceso educativo.

DESCRIPTORES: Docentes. Educación en salud. Capacitación profesional. Competencia profesional.

\section{INTRODUCTION}

In Brazil, government measures have promoted the restructuring of healthcare professionals' training. Unpreparedness or lack of didactic and pedagogical specificities of health care is, however, limiting to the desired advances. This scenario indicates that pedagogical preparation in healthcare teaching is determinant and strategic to the transformations in the area's professional training and exercise.

Most Brazilian higher education institutions (HEIs) require specific knowledge of the intended discipline as a prerequisite to teaching, coming from professional exercise (practical) and academic training (theoretical), but not the didactic-pedagogical preparation of the candidate as a competence. Moreover, faculty progression emphasizes scientific production, with emphasis on research and specific knowledge as criteria for evaluating faculty productivity and teaching, placing teaching as a competitor of research, and dichotomizing teaching, research and extension. ${ }^{1-2}$

Constructed through the mediation between specific knowledge and the accessible and comprehensible offer of these assets to students, teaching starts from the daily practice recognition, as well as from recurrent attitudinal and decision-making reflection..$^{3-4}$ Shulman proposes seven categories of basic knowledge for teaching, which are necessary for professors to develop a competent pedagogical practice, namely: content; general pedagogical knowledge; pedagogical content knowledge; curriculum knowledge; knowledge of learners and their characteristics; knowledge of educational contexts; and knowledge of educational ends, purposes, and values, and their philosophical and historical grounds. ${ }^{5}$

In this perspective, the reality of the healthcare education world focused in this study can only be transformed from man's recognition of himself and others, with the perception that their own situation can be modified, and taking into account the context in which they are inserted. ${ }^{6}$ This should be the purpose of professional training when the transformation of healthcare practices is desired.

World awareness, which is intimately connected to self-awareness, can be considered the professors' understanding of their world, since it is through it that professors can apprehend and transform their reality. From their world awareness, professors can develop the naive world awareness, seeing only what is before their eyes, without depth or reflection. This posture does not recognize the importance of developing the knowledge necessary for teaching practice in themselves, resulting in actions that do not contribute to reality change and, consequently, nor to improving teaching quality. ${ }^{6}$

The importance of this research development for the profession is justified, because based on the recognition, analysis and understanding of how basic knowledge for the teaching of healthcare professors is developed for a transformative pedagogical practice, it is possible to contribute to their initial and continuous training, making them active, autonomous and reflexive subjects within the learning process. Therefore, it is possible to adopt emancipatory theoretical frameworks, reflecting the analysis of educational contexts and interpersonal relationships between professors and students, and providing differentiated training to future healthcare professionals.

In view of the scenario above, the objective of this study was to understand how naive world awareness is expressed in the pedagogical practice of healthcare professors, based on Shulman's basic knowledge categories ${ }^{5}$ and on Paulo Freire's concept of naive world awareness. ${ }^{6}$ It is important to note the importance of the interrelation between these two authors, whose principles complement 
each other and defend education as a politicalsocial act, believing that there are fundamental elements that can contribute to qualified and competent training of professors.

\section{METHOD}

This qualitative research, using a descriptive, exploratory and analytical approach, was developed in a public university of the Southern Region of Brazil. It was carried out in a public institution because in this type of institution professors enter from public competition and, thus, build a career, with little turnover, different from private institutions. The criterion of participant choice was the intentional search of professors in the health care area whose initial training had included nursing, medicine, dentistry, pharmacy, nutrition, phonoaudiology and physical education. They should work in the following courses: nursing, medicine, dentistry, pharmacy, nutrition and phonoaudiology.

As per Shulman, ${ }^{5}$ intermediate professors should have 6 to 14 years of experience, which was the criterion adopted to be included in the study or not. The selection of participants was based on a search on the institutional website of each undergraduate course. Then, the professors' Lattes curriculums were accessed, in order to know their professional trajectories and identify if they fit the inclusion criterion. After consultation with the Lattes curriculum, the educational department to which the professor was linked was contacted and, later, so were the participants. The first contact with participants was made by invitation or e-mail to participate in the research. Data collection was scheduled at that moment.

Fifty-four intermediate professors were identified during the data collection period, 16 of whom had initial education in medicine, ten in pharmacy, nine in dentistry, nine in phonoaudiology, five in nutrition, four in nursing and one in physical education. It should be noted that the researcher contacted all possible participants; 17 of them did not accept to participate in the research, nine were out of the country conducting postdoctoral training, and seven were away from the university on sick leave.

Thus, 21 professors accepted to participate in the research, but only 11 fit its objectives, because they demonstrated naive world awareness characterized by the non-recognition of developing the knowledge necessary for the teaching practice in themselves. The central category and its subcategories emerged from interviews and observations of the following professors: five physicians, two phonoaudiologists, a dentist, a pharmacist, a nutritionist, and a physical educator.

Data collection was carried out from May to December 2013. Data were collected through an open interview and non-participant observation. The open interview guiding question was: How did you become a professor? Interviews had minimum and maximum duration of nine and eighteen minutes, respectively.

A digital recorder was used for the interviews, which were transcribed in full. The non-participant observations were scheduled after the interview, according to the participant's availability, and one observation was performed for each interviewee. The observation could be in any teaching environment: classroom, laboratory class and/or experience in clinical practice fields. Observations had a minimum duration of one hour/class and a maximum of four hours/class. It should be noted that the objective and subjective records of non-participant observations were made in a field diary (notebook), oriented as per the following aspects: organization and class planning; contents taught; how the lesson takes place and what resources are used and made available to students; class development with students; topics covered; forms of student participation; attitude towards one's teaching role: how the teaching process is guided; learning content for students; evaluation process of the contents studied; are students provided with their practical experiences to enrich theory?; are knowledge and critical content view demonstrated?; is pedagogical support during classes expressed?; is engagement in the curricular context demonstrated?; is engagement in the educational context demonstrated?; are examples of one's own actions on content given?; are students brought closer to reality by connecting to the various contents that permeate teaching? are beliefs and values demonstrated during the pedagogical practice?

Data were analyzed through the Minayo's operative proposal, ${ }^{7}$ which consists of three steps: pre-analysis, organized from repeated and exhaustive readings of interview transcripts, with data organized into a Microsoft Office Word ${ }^{\circledR}$ program file; data exploration, which consists of first, second and third encoding of raw data, thus capturing the central data ideas, which were organized in Microsoft Office Excel ${ }^{\circledR}$; and treatment and interpretation of the results obtained, done from the approximation of the data to the theoretical framework of Paulo Freire, bringing about the following central 
category: "Naive world awareness of healthcare professors". At that moment, data were integrated to the basic knowledge categories proposed by Shulman, which became subcategories and starting points for data grouping and interpretation. These were again confronted with Freire's framework, thus re-elaborating new subcategories.

This project was submitted to the Ethics Committee of the Federal University of Santa Catarina, as recommended by Resolution 466/126 of the National Health Council, and was approved under the Committee protocol $270.874 .^{8}$ Professors' acceptance to participate in the research was obtained by signing a free and informed consent form. To ensure anonymity, participants were designated by identification codes chosen by the researcher. The initial codename was maintained, adding the letter "O" at the end; for example: "Marcos O".

\section{RESULTS}

This study presents the central category as a result: Naive world awareness of healthcare professors, which comprises the subcategories presented below.

\section{Nonknowledge of content: teaching is transferring knowledge}

This category was related to the specific lack of knowledge of a discipline or content and its theoretical principles. From the observation description, it was observed that professors had weaknesses in the knowledge of the specific content and in the integration of other contents, when they transferred the responsibility of answering students' questions to another person, and did not relate the specific content to other knowledge during the educational process. The lesson is about in vitro dissolution. The professor presents the content in Power Point, slides are very loaded with information and have no illustrations. The professor reads what is written in full, speaks quickly and at no time asks anything, or interacts with the class. The lecture about the content is punctual on each slide, seeming memorized. A student asks a question about the subject and the professor says that content does not belong to her class, and that the student can take this question to professor $M$ (Flavia $\mathrm{O}$ ).

\section{General pedagogical nonknowledge: teaching is reproducing what has been learned}

This subcategory refers to the professor's fragility in relation to teaching knowledge, to educational conceptions and principles with the use of pedagogi- cal strategies, thus transcending the knowledge of the specific subject. It was interesting and very difficult [the experience as a professor] because, first of all, there is no training anywhere. We graduate without any didactic content or training. So, one way or another, we reproduce what we have learned, but with a very long time distance between the time we were graduate students and the time we start teaching classes at undergraduate programs. In fact, we have no option, we can only reproduce and pass the message on (Nilton $\mathrm{O}$ ).

On the one hand, although the professor recognized the importance of pedagogical training, he did not mobilize himself to recognize a movement to improve his practice, placing himself in a passive and conformed position.

\section{Pedagogical content nonknowledge: learning requires mechanical memorization}

At times, the development of pedagogical content knowledge was perceived in a disjointed way in observations made with the professors. The theme of the lesson is the health reform movement. The professor speaks in a high tone, is serious and gestures with a hand in his pocket, uses a far-fetched language, with specific terms difficult to understand. All content seems to be very detached from the students' reality [first phase of the course], and it does not bring practical examples or analogies. Students commenting that they are sleepy with each other, some are using the computer or cell phone. The professor talks about the preventivist care model and social medicine. In the same context, he speaks of Marx, but does not ask about the group's knowledge about the philosopher. He also speaks of dialectical-historical materialism (Emerson $\mathrm{O}$ ).

Still in this category, it was possible to observe the difficulty in maintaining classroom organization and management through the professor's report, when he tried to create group discussion during the class. [...] sometimes, in some classes, I even try to create group discussions, only it depends on the semester. When the class is very large, I lose control, so it gets difficult, it's a lot of talk, I cannot pay attention to all groups, and two class hours fly by, and I cannot manage the time it takes to do the activity. So I end up preparing more expository classes with the help of PowerPoint, which are easier and more practical [...] (Fabiana O).

\section{Nonknowledge of learners and their characteristics: learners are passive objects that know nothing}

This subcategory was characterized by the non knowledge of the cognitive, social, cultural 
and psychological singularities of students, as well as of the interests and needs that each one brings with oneself to the educational moment. [...] there are 50 students per semester, plus students from the other phases that we come in contact with. There is no way to know who each student is, I hardly know their names, one student or another is more involved or more exposed, or those you guide in the end-of-course paper, who I get to know, otherwise, no. A semester goes by and there is another group of 50 students, and there is no way to get to know or approach them (Manuela $\mathrm{O}$ ).

\section{Nonknowledge of the curriculum: the program should be lectured}

It referred to the lack of awareness of the curriculum organization, the disciplines and syllabus, the training objectives and understanding of the materials and programs that served as fundamental elements for the professors' work process. [...] we now have the first classes of the new curriculum, and since I did not participate in the discussions of these disciplines for the new curriculum, I cannot say what people thought when they chose this curriculum format, these subjects, this schedule. This I really do not have, I'm just fulfilling what the syllabus says now (Marcos O).

One aspect that stood out was the lack of knowledge and/or confusion of professors about the meaning of the politico-pedagogical project (PPP) and pedagogical training, and it was possible to infer that there were limitations regarding the curriculum knowledge of the courses in which they worked [the question asked was about PPP knowledge]. Project? If you had a career plan, something like this? So, over there at [...], I went through two phases, at the time, that was not a company, and then a group of shareholders bought it and transformed it into another institution. When I got in, we had more pedagogical support, I had to do training. The first three years were excellent, there were many training courses during vacation, which were mandatory for us. Regarding methodology, professors came from outside to give classes on how to encourage students. It was face-to-face and it counted for progression. It was great for the career (Francine O).

\section{Nonknowledge of the educational context: education is an apolitical act}

This subcategory referred to the lack of knowledge and information about the field in which the professor acted, such as policies, norms and routines. The professor did not perceive educational management as an important locus of political coordination: [...] of course, as every position at [...], I was given a bureaucratic position coordinating internships. And that I never understood very well, it seems to me like something ignorant intended by the institution. A new doctor spending ten hours a week to sign documents is very expensive training, someone who leaves the doctorate and always comes out overwhelmed with work. I do not understand that the institution ends up diverting a doctor who is being trained to teach to another type of function, as it is, and this happens [...] (Nilton O).

For the professor, taking over administrative activities consisted in a deviation from the function, and interfered in his dedication to teaching (work overload and bureaucratic activities). From this perspective, the concept of teaching seemed reduced to "teaching classes", that is, passing on content. It was pointed out that the knowledge of the demand for the education of a new professional aligned with the principles and guidelines of Brazilian health care policy did not appear in the speeches, nor was there any reference to governmental efforts to reorient health care training.

\section{Nonknowledge of educational ends, purposes, and values, and their philosophical and historical grounds: education is training}

It referred to the lack of knowledge about the objectives of education and training, their historical construction bases and their theoretical and philosophical support. Professors were thus able to have clarity of what skills and competences students needed to develop through the educational context in which they were immersed: [...] I worked in a private university for some time, I taught physiotherapy students, but it was not an experience I liked, because [...] the quality of teaching is far worse than it should be. That thing when the student paid the tuition as if it were a car, and in the end he will leave with a diploma [...]. When I wanted to demand, I made a point of teaching there [...] I do not know whether or not it has a politico project, it was not presented to me (Marina O).

\section{DISCUSSION}

The training of professors consists of an important and difficult policy to be implemented, still realizing the validity of the traditional pedagogical model, in which the disarticulation of content knowledge with pedagogy and the fragilities in the professor-student interaction are perceptible. Thus, the specific preparation of professors becomes a sine qua non condition for the education of future professionals who are autonomous, critical, reflective and co-responsible for their permanent education process. 
Based on the results presented in the first subcategory, "Nonknowledge of content: teaching is transferring knowledge", the professors' attachment to the transfer of knowledge is evident, remaining in their "comfort zone", that is, the professor gets used to developing activities that offer constant, but restricted performance. This bring a sense of security, which does not cause fear, anxiety or any kind of risk, and does not seek to problematize the questions raised in class.

The lack of specific preparation for the teaching activity and the education of trainers as one of the main reasons for the reproduction of the models and practices experienced as students by current professors show that this fact is commonplace in healthcare trainers' practice, emphasizing that the pedagogical content is constructed and transformed by practical experiences and by daily teaching practice. ${ }^{9-10}$

It is thus emphasized that the naive world awareness is seen as a static world view which does not allow men to question or have change initiatives in the face of the realities presented. Thus, naive world awareness can catalyze and frame truths over time, limiting professors' autonomy to reflect and reinterpret their context, making them passive in the face of the decisions and changes that the educational process reality requires. ${ }^{11}$

Another relevant aspect that emerged on the students' evaluation is that it ends up being restricted to classroom attendance and written test performance. A coherent evaluation aims to consider the student as a being immersed in a culture, with singular characteristics and needs, with potential for evolution, who needs to be evaluated in a procedural and qualitative way, with fairness and ethics. ${ }^{12}$

From the moment educators conceive evaluation as a politico-pedagogical act, students are transformed into autonomous beings with the ability to construct their knowledge, correlating it to their reality, with curiosity and eagerness for change. The view of the learners as shallow tabs, who know nothing and must be filled by the educator, and evaluation as a measure of each student's deposit capacity aims at depository and technical training, which makes learners passive, oppressed and leaves them with no autonomy. ${ }^{6}$

The findings provide evidence that there is pedagogical content nonknowledge, in which teaching is associated with mechanical memorization. It is necessary to transpose this long lasting educational model based on traditional teaching, with the pro- fessor having the role of transmitting knowledge, and the student of memorizing content, without seeking reflection and critical understanding.

The development of competences related to autonomy is in line with the creation of teaching strategies that allow students to develop this practice, becoming autonomous, critical and reflective professionals. Autonomy requires students to participate in their educational process, becoming co-responsible for it. For this, professors must play an essential and irreplaceable role in this movement: the role of those responsible for mediating the process and stimulating students. ${ }^{13}$

In the subcategory "Nonknowledge of learners and their characteristics: learners are passive objects that know nothing", there is great concern about the data that emerged, because the lack of bonds with students evidenced by professors directly interferes with the educational process. The learner is not a blank page, in which professors print their knowledge. Students cannot be seen as mere spectators in the educational process. Professor and student teach and learn: both are protagonists of this process.

In some cases, the processes of deconstruction and reconstruction of educators are necessary, and they have to reflect on the contents worked in the classroom, and also allow for a change in attitude, trying to be more open with students, valuing their prior experiences and knowledge, and recognizing them as unfinished. This way, it will be possible to establish a dialogical relationship, focusing on learning and relating curricular contents and the various situations of the social and healthcare context, in which the actors of this process are inserted and mutually respect. ${ }^{14}$

Regarding the "Nonknowledge of the curriculum: the program should be lectured", it was identified that the professor complies with what is described in the syllabus for the subject, without concern for the relations that it has in the professional training process, which are explicit in the PPP. A syllabus guides the professor in the organization of the pedagogical work, but the unfolding from it (selection of contents, schedules, learning methods/experiences) needs to be coordinated with the whole of the students' training process. This position indicates a weakness of the student, with respect to the knowledge and importance attributed to the curriculum.

The competent pedagogical practice demands from professors resources to support it, and knowing the curriculum and the politico-pedagogical project, besides the orientation policies of the training, which 
facilitates the performance of their role according to course characteristics, in order to encourage students to go beyond what is proposed. This knowledge is also necessary for reflection on the aspects addressed in these documents, which show the need for changes that allow students to become more involved in the construction of knowledge and in relation to the political and social context. ${ }^{15}$

When thinking about curriculum, one immediately thinks of the evaluation process, because it leads the curriculum to progress and improvements, or to succumbing to the daily sameness. Transformations of evaluation attitudes require, above all, a revision of the conceptions professors bring with them about education, knowledge and teaching; they also require thinking about a politico-pedagogical project based on the education of autonomous and reflective citizens. ${ }^{13}$

Curricular limitations associated with the difficulty of conducting discussions, the interaction of students in class and the use of different methodologies can be based on innumerable causes, leading the professor to assume a traditional attitude, which is still hegemonic and offers a sense of control of the teaching and learning process - albeit false. This is because the creation of innovative and active teaching strategies requires specific skills and knowledge from the professor, which go beyond their mere use.

Education is a form of world intervention - an intervention that goes beyond content knowledge. Educating is a political act that implies, in addition to efforts to reproduce the dominant ideology, the reflection about it, its unmasking and its transformation. Educating requires the understanding that the educating being is inserted in a reality, which needs to be understood, discussed and reflected, so there can be transformations. The mere transmission of content, without insertion into a political, administrative, bureaucratic and interpersonal reality may train professionals, but it is not capable of educating citizens. ${ }^{6}$

However, it should be noted that the participants recognize the existence of problems that directly interfere in the pedagogical practice and, consequently, in students' active participation, such as professors' workload and high number of students in the classroom, which hinders dialogue and recognition of their needs. In this way, professors can also be seen as hostages of their often exhausting and inhuman work process. On the other hand, it is expected that professors assume their role as political actors, understanding the broad educational context and being able to help students to take the lead role of their education process, with the understanding of their responsibility as social subjects, transformers of the reality in which they are inserted.

The last subcategory refers to the "Nonknowledge of educational ends, purposes, and values, and their philosophical and historical grounds: education is training". Only one professor expressed in an incipient way the importance of having clear educational objectives, purpose and values that permeate this process, as well as its historical-philosophical foundations. This result shows the need to broaden discussions with professors about their own work process, so they can see their real role as educators in the health care scenario more clearly.

A depository practice is damaging when adopted by professors, and some of these damages are irreversible to students, who become domesticated, trained, limited beings, with difficulties to be inserted in the world. For this reason, the emancipation of students is sought. The emancipation of men emerges as a political conquest to be effected by human praxis. ${ }^{6}$ Turning to education, it is observed that educators who are committed to a transformative PPP develop their teaching aiming to assist in the construction of students' autonomy, valuing and respecting their culture and their previous knowledge, acquired outside the educational context.

Education, in this juncture, is seen as a possibility of training students. In order to reverse this situation, there is a need for constant evaluation of the educational process, and for professors to have an ethical-social commitment that also involves the principles of dialogue, democracy, solidarity, inclusion, participation, and justice. Hence, it is possible to raise the awareness of professors and students about their rights and duties, as well as to favor the overcoming of weaknesses and appreciation of learning throughout the process. These aspects give rise to the action-reflection-action process in the evaluative context, promoting the loss of the measurement character, and emphasizing the importance of the commitment to educate professionals with human values. ${ }^{16}$

It is also known that empirical knowledge, despite its recognized relevance, is not enough to achieve success in the training of healthcare professionals. Professors must master the pedagogical knowledge of the content in order to develop the subject considering students' reasoning, clarifying doubts, using examples and broadening the vision of the theme proposed. It is necessary to consolidate disciplinary and pedagogical knowledge, which 
benefit the exercise of the educational process appropriately, focusing on the specificity of the teaching function, and distinguishing it from the attitude of a specialist in a particular discipline. ${ }^{15}$

\section{CONCLUSION}

The naive awareness of healthcare professors demonstrates a scenario in which health care education is still based on technical rationality, where the teaching practice consists in knowing and doing, and sticking to it. In this context, professional training is based on the strengthening of technical capacity, and weakening of the political dimension, fostering technical education without a transformative perspective.

It is necessary to transform naive awareness, based on the awareness of the incompleteness of being, and which is based on the transformation of reality and education for meaningful and quality training. The training of professors should consist of strategies aimed at promoting their awareness, but spaces for discussion and reflection of the teaching practice in healthcare education are still isolated practices, and there is a mismatch in the permanent training of professors, generating a complex challenge for education institutions, and fostering the persistence of naive awareness among professors.

\section{REFERENCES}

1. Prado ML, Testoni AK, Kempfer SS, Ferraz F, Lopes $\mathrm{CR}$, Bernardi MC. Formative evaluation of the nursing program at a university in the south of brazil: technological tool to the approach of the unified health system. Open journal of social sciences. [Internet]. 2014 [cited 2015 nov 20]; 4(2):1-6. Available from: http://dx.doi.org/10.4236/jss.2014.22001

2. Costa RK, Miranda FA. Sistema Único de Saúde e da família na formação acadêmica do enfermeiro. Rev Bras Enferm [Internet]. 2009 [cited 2016 Feb 29]; 62(2):300-4. Available from: http://www.scielo.br/scielo.php? script=sci arttext\&pid=S0034-71672009000200021

3. Medeiros Z, Coelho ML, Rückert B, Nonato BF, Carmo HC. Aprendizagem colaborativa em cursos semi-presenciais de formação em docência do ensino superior. Revista Docência do Ensino Superior [Internet]. 2015 [cited 2016 Feb 29]; 20(2):42-52. Available from: https://seer.ufmg.br/ index.php/rdes/article/view/967/0

4. Oliveira LB, Melo VF, Rouiller AP, Ferreira NC, Carneiro TA, Püschel VA. Estratégias de avaliação da aprendizagem aplicadas no ensino de graduação em enfermagem no Brasil. Invest Educ Enferm [Internet]. 2015 [cited 2016 Feb 29]; 5(1):57-62.
Available from: http://www.enfermeria21.com/ revistas/aladefe/articulo/151/

5. Shulman LS. Conocimiento y enseñanza: fundamentos de lanueva reforma. Profesorado [Internet]. 2005 [cited 2016 Feb 29]; 9(2):1-30. Available from: http://www.ugr.es/ recfpro/ rev92ART1.pdf

6. Freire P. Pedagogia do oprimido. 57a ed. São Paulo: Paz e Terra; 2014.

7. Minayo MC. O desafio do conhecimento: pesquisa qualitativa em saúde. 12a ed. São Paulo: Hucitec; 2011.

8. Ministério da Saúde (BR). Conselho Nacional de Saúde. Resolução n. 466, de 12 de dezembro de 2012 [Internet]. Brasília, DF: Ministério da Saúde: 2012 [cited 2016 Feb 29]. Available from: http:// bvsms.saude.gov.br/bvs/saudelegis/cns/2013/ res0466_12_12_2012.html

9. Backes VM, Medina-Moya JL, Prado ML. The construction processo $f$ pedagogical knowledge among nursing professors. Rev Latino-Am Enfermagem [Internet]. 2011 [cited 2016 Mar 3]; 19(2):421-8. Available from: http://www.scielo.br/ $\mathrm{pdf} / \mathrm{rlae} / \mathrm{v} 19 \mathrm{n} 2 / 26$.pdf. Portuguese

10. Costa RK, Miranda FA. Opinião do graduando de enfermagem sobre a formação do enfermeiro para o SUS: uma análise da FAEN/UERN. Esc Anna Nery [Internet]. 2010 [cited 2016 Feb 29]; 14(1):3947. Available from: http://www.scielo.br/pdf/ean/ v14n1/v14n1a07

11. Bazanella SL, Faveri JE. A consciência ingênua como pressuposto e perfil da educação regional. Rev Luminária [Internet]. 2012 [cited 2016 Feb 29]; 3(13):19-33. Available from: http://www.unc.br/ mestrado/docs/a_consciencia_ingenua_como_ pressuposto_e_perfil_da_educacao_regional.pdf

12. Ramos FR, Borges LM, Brehmer LC, Silveira LR. Formação ética do enfermeiro: indicativos de mudança na percepção de professores. Acta Paul Enferm [Internet]. 2011 [cited 2016 Feb 29]; 24(4):48592. Available from: http://www.scielo.br/pdf/ape/ v24n $4 / \mathrm{a} 07 \mathrm{v} 24 \mathrm{n} 4$

13. Waterkemper R, Prado ML, Medina-Moya JL, Backes VM. From being to yourself to become to be: on development of autonomy construction in nursing students. Invest Educ Enferm [Internet]. 2014 [cited 2016 Feb 29]; 32(1):33-40. Available from: http://www.scielo.org.co/pdf/iee/v32n1/ v32n1a04.pdf

14. Canever BP, Prado ML, Gomes DC, Kempfer SS. Conhecimento de si do docente da área da saúde: uma reflexão em Freire. Rev Enferma. UFSM [Internet]. 2015 [cited 2016 Feb 29]; 5(3):379-86. Available from: http://cascavel. ufsm.br/revistas/ojs-2.2.2/index.php/reufsm/ article/view/13016

15. Backes VM, Medina-Moya JL, Prado ML, Menega JC, Cunha AP, Francisco BS. Expressões do 
conhecimento didático do conteúdo de um professor experimentado de enfermagem. Texto Contexto Enferm [Internet]. 2013 [cited 2016 Feb 29]; 22(3):804-10. Available from: http:/ / www.scielo.br/ $\mathrm{pdf} / \mathrm{tce} / \mathrm{v} 22 \mathrm{n} 3 / \mathrm{v} 22 \mathrm{n} 3 \mathrm{a} 29$. pdf

16. Lopes MM, Real GC, Bagnato MH. A percepção de egressos sobre as transformações curriculares ocorridas no curso de graduação em enfermagem. ETD-Educação Temática Digital [Internet]. 2012 [cited 2016 Feb 29]; 14(2);275-89. Available from: http://periodicos.bc.unicamp.br/ojs/index.php/ etd/article/view/1234 